\title{
High Temperature Enhances the Resistance of Cultivated African Rice, Oryza glaberrima, to Bacterial Blight
}

Gerbert Sylvestre Dossa, Plant Breeding, Genetics, and Biotechnology, International Rice Research Institute (IRRI), Los Baños, Philippines; and Department of Phytomedicine, Leibniz Universität Hannover, Hannover, Germany; Ricardo Oliva, Plant Breeding, Genetics, and Biotechnology, IRRI; Edgar Maiss, Department of Phytomedicine, Leibniz Universität Hannover; Casiana Vera Cruz, Plant Breeding, Genetics, and Biotechnology, IRRI; and Kerstin Wydra, Department of Phytomedicine, Leibniz Universität Hannover; and Plant Production and Climate Change, Erfurt University of Applied Sciences, Erfurt, Germany

\begin{abstract}
Dossa, G. S., Oliva, R., Maiss, E., Vera Cruz, C., and Wydra, K. 2016. High temperature enhances the resistance of cultivated African rice, Oryza glaberrima, to bacterial blight. Plant Dis. 100:380-387.

Rice bacterial blight $(\mathrm{BB})$ is caused by Xanthomonas oryzae pv. oryzae and is responsible for substantial yield loss worldwide. Host resistance remains the most feasible control measure. However, pathogen variability leads to the failure of certain resistance genes to control the disease, and climate change with high amplitudes of heat predisposes the host plant to pathogen invasion. Due to pressure in natural selection, landrace species often carry a wide range of unique traits conferring tolerance of stress. Therefore, exploring their genetic background for host resistance could enable the identification of broad-spectrum resistance to combined abiotic and biotic stresses. Nineteen Oryza glaberrima accessions and $O$. sativa rice variety SUPA were evaluated for BB resistance under high temperature $\left(35\right.$ and $31^{\circ} \mathrm{C}$ day and night, respectively) using $14 X$. oryzae $\mathrm{pv}$. oryzae strains originated from the Philippines. Under normal temperature,

most of the accessions showed resistance to 9 strains $(64.3 \%)$ and accession TOG6007 showed broad-spectrum resistance to 12 strains (85.7\%). Under high temperature, most accessions showed a reduction in BB disease, whereas, accession TOG5620 showed disease reduction from all the $X$. oryzae pv. oryzae strains under high temperature. Molecular characterization using gene-based and linked markers for BB resistance genes $X a 4, x a 5, X a 7, x a 13$, and $X a 21$ revealed the susceptible alleles of $X a 4$, $x a 5, x a 13$, and $\mathrm{Xa21}$ in $O$. glaberrima. However, no allele of $\mathrm{Xa}$ ( was detected among $O$. glaberrima accessions. Our results suggest that $O$. glaberrima accessions contain a BB resistance different from the $\mathrm{Xa}$ gene type. Genome-wide association mapping could be used to identify quantitative trait loci that are associated with BB resistance or combined $\mathrm{BB}$ resistance and high-temperature tolerance.
\end{abstract}

Rice bacterial blight (BB) caused by Xanthomonas oryzae pv. ory$z a e$ is one of the most important bacterial diseases in rice. Reported in several rice-producing countries in Asia and Africa, rice BB affects rice production worldwide. Thus, rice- $X$. oryzae pv. oryzae interaction leads to severe yield losses in major rice ecosystems. Host resistance is still the most economically effective control measure against the disease and, thus far, 39 rice resistance $(R)$ genes have been identified against Asian $X$. oryzae pv. oryzae populations (Khan et al. 2014; Natraj Kumar et al. 2012; Zhang et al. 2015). However, in Africa, up till now, there has been no $R$ gene identified to control this disease. The effectiveness or durability of host-plant resistance may be affected by climate change (Reddy 2015).

Climate change, with air temperature increase and water scarcity, will affect world agricultural production. Several reports have shown the effects of global warming on pathogen and host plant alike. Increase in temperature predisposes the host plant to pathogen colonization. Webb et al. (2010) reported an increase in BB disease on rice near-isogenic lines carrying single $\mathrm{Xa3}, \mathrm{Xa} 4, \mathrm{xa} 5$, and $\mathrm{Xa1O}$ genes, with $X a 4 R$ genes mostly under high temperature; however, the effectiveness of BB $R$ gene $X a 7$ was enhanced under the same conditions. Similarly, the wheat stripe rust $R$ gene $Y r 36$ confers broad-spectrum resistance to Puccinia striiformis f. sp. tritici at high temperature $\left(25\right.$ to $35^{\circ} \mathrm{C}$ ) and shows susceptibility to the pathogen at low temperature $\left(15^{\circ} \mathrm{C}\right)$ (Uauy et al. 2005). Therefore, there is an urgent need to

\section{Corresponding author: G. S. Dossa; E-mail: c.dossa@irri.org}

*The $\boldsymbol{e}$-Xtra logo stands for "electronic extra" and indicates that one supple-
mentary table is published online.

Accepted for publication 11 July 2015.

http://dx.doi.org/10.1094/PDIS-05-15-0536-RE

(C) 2016 The American Phytopathological Society develop cultivars with resistance to or tolerance of BB to sustain rice production under changing climate conditions. Oryza glaberrima is known to possess many important traits.

Oryza glaberrima $(2 n=14$, AA) is the second most important cultivated rice worldwide. It was domesticated in West Africa in the Niger River Delta more than 3,500 years ago (Yves et al. 2012). Because of its low-yielding characteristic, O. glaberrima was progressively abandoned for $O$. sativa, the Asian cultivated rice, which has a higher yield (Jones et al. 1997). However, because of its adaptation to African climate conditions, $O$. glaberrima is still grown in some West African countries. Although the high-yielding cultivars of $O$. sativa are preferred, their adaptation to the adverse conditions of the local environment is not satisfactory. O. glaberrima is well known to possess many useful traits, such as resistance to blast, Rice yellow mottle virus, sheath blight, nematodes, stem borer, hispa, stalk-eyed fly, the African gall midge for weed competitiveness, and BB (Alam and Efron 1986; Albar et al. 2006; Baggie et al. 2002; Djedatin et al. 2011; Lorieux et al. 2003; Maji et al. 2001; Ndjiondjop et al. 1999; Nipah et al. 1997; Nwilene et al. 2002; Sahrawat and Sika 2002; Silue and Notteghem 1991; Thiémélé et al. 2010; Wang et al. 1996); and tolerance of drought, submergence, soil acidity, salt, iron, and aluminum. Interestingly, notable traits from $O$. glaberrima have been combined with high-yielding traits of $O$. sativa to generate the New Rice for Africa (Jones et al. 1997). Vikal et al. (2007) have identified 13 O. glaberrima accessions with resistance to Indian $X$. oryzae pv. oryzae pathotypes, and a narrow genetic base for resistance to $X$. oryzae pv. oryzae among 107 accessions of $O$. glaberrima was reported (Djedatin et al. 2011).

Natural selection often generates wild species with diverse traits, such as disease resistance, that could be inherited by wild relatives (Das et al. 2014). Thus, $R$ genes were identified from wild rice. For example, BB $R$ gene $X a 21$, which confers resistance to several Philippine $X$. oryzae pv. oryzae races, was identified from African rice $O$. longistaminita. Identification of $R$ genes from African rice would enable breeding of resistance cultivars not only against the 
African $X$. oryzae pv. oryzae population but also against the Asian $X$. oryzae pv. oryzae. Discovery of new, large-spectrum $R$ genes will contribute to the control of rice $\mathrm{BB}$ disease in the future. To our knowledge, there is no report available on the combination of high temperature and $\mathrm{BB}$ stress on $O$. glaberrima. This study aims to

Table 1. List of rice accessions and Xanthomonas oryzae pv. oryzae strains

\begin{tabular}{|c|c|c|c|}
\hline Sample number & $\begin{array}{l}\text { Accession or } \\
\text { strain name }^{\mathbf{a}}\end{array}$ & $\begin{array}{c}\text { Accession number } \\
\text { or race }\end{array}$ & Origin \\
\hline \multicolumn{4}{|l|}{ Africa } \\
\hline 1 & $\mathrm{CG} 17^{\mathrm{c}}$ & IRGC 86741 & Senegal \\
\hline 2 & RAM90 & na & Mali \\
\hline 3 & RAM98 & na & Mali \\
\hline 4 & SUPA $^{c}$ & IRGC 69789 & Tanzania \\
\hline 5 & TOG5293 & IRGC 96725 & Nigeria \\
\hline 6 & TOG5447 & IRGC 96756 & Nigeria \\
\hline 7 & TOG5458 & na & Mali \\
\hline 8 & TOG5464 ${ }^{\mathrm{c}}$ & IRGC 96760 & Nigeria \\
\hline 9 & TOG5473c & IRGC 104534 & Nigeria \\
\hline 10 & TOG5523 & IRGC 86757 & Nigeria \\
\hline 11 & TOG5566 ${ }^{\mathrm{c}}$ & IRGC 96779 & Nigeria \\
\hline 12 & TOG5620 & IRGC 86764 & Ghana \\
\hline 13 & TOG5650 & IRGC 104543 & Nigeria \\
\hline 14 & TOG5675 & IRGC 96791 & Nigeria \\
\hline 15 & TOG5810 & IRGC 86784 & Liberia \\
\hline 16 & TOG5953' & IRGC 96811 & Nigeria \\
\hline 17 & TOG5989c & na & Nigeria \\
\hline 18 & TOG6007 & IRGC 96824 & Nigeria \\
\hline 19 & TOG6231 & IRGC 96854 & Mali \\
\hline 20 & TOG7173 & IRGC 96893 & Nigeria \\
\hline \multicolumn{4}{|l|}{ Asia } \\
\hline 1 & PXO61 & Race 1 & Philippines \\
\hline 2 & PXO86 & Race 2 & Philippines \\
\hline 3 & PXO79 & Race $3 b$ & Philippines \\
\hline 4 & PXO340 & Race 3c & Philippines \\
\hline 5 & PXO71 & Race 4 & Philippines \\
\hline 6 & PXO112 & Race 5 & Philippines \\
\hline 7 & PXO99 & Race 6 & Philippines \\
\hline 8 & PXO145 & Race 7 & Philippines \\
\hline 9 & PXO280 & Race 8 & Philippines \\
\hline 10 & PXO339 & Race 9a & Philippines \\
\hline 11 & PXO349 & Race $9 b$ & Philippines \\
\hline 12 & PXO347 & Race 9c & Philippines \\
\hline 13 & PXO363 & Race 9d & Philippines \\
\hline 14 & PXO341 & Race 10 & Philippines \\
\hline
\end{tabular}

a Accession name according to AfricaRice (Cotonou, Benin).

b Accession number according to the International Rice Research Institute (Los Baños, Philippines) germplasm database; na $=$ not available.

${ }^{c}$ Accessions selected for combined high temperature and bacterial blight experiment. evaluate selected accessions of the cultivated $O$. glaberrima to a combination of high temperature and BB stresses.

\section{Materials and Methods}

Plant materials. In all, 19 accessions of $O$. glaberrima (Table 1) were obtained from the Africa Rice Center gene bank (Cotonou, Benin), with the help of Dr. Drissa Silue. The 19 accessions, which originated from West African countries (Ghana, Liberia, Mali, Nigeria, and Senegal), were selected according to their resistant reaction to African $X$. oryzae pv. oryzae strain Mail and Asian $X$. oryzae pv. oryzae race 2 strain PXO86 (Djedatin et al. 2011). We also included $O$. sativa variety SUPA (accession IRGC 69789) because it is one of the most preferred varieties in East Africa. One set of plants was grown under greenhouse conditions (12-h day length). To evaluate the combination of high temperature and $X$. oryzae pv. oryzae, the plants were grown under greenhouse conditions for 21 days and then transferred into a growth chamber $(12 \mathrm{~h}$ of light and $12 \mathrm{~h}$ of darkness; 35 and $31^{\circ} \mathrm{C}$ day and night temperatures, respectively; and $80 \%$ relative humidity).

BB inoculation and evaluation. Fourteen strains (Table 1) representative of $10 \mathrm{X}$. oryzae pv. oryzae races from the Philippines (Cottyn and Mew 2007) were used in this study. Strains were grown on Modified Wakimoto's medium, as described by Leach et al. (1992), for $72 \mathrm{~h}$. The inocula were prepared by suspending the harvested bacterial cells in demineralized sterile water. Approximately $10^{8} \mathrm{CFU} / \mathrm{ml}$ of each inoculum was used to inoculate the plants with the use of the leaf-clipping inoculation method (Kauffman et al. 1973) 4 weeks after sowing, under greenhouse conditions and in a growth chamber at 35 and $31^{\circ} \mathrm{C}$ (day and night, respectively). Disease assessment was done by measuring lesion length 14 days after inoculation. Two replicated trials were performed, each trial consisting of three replicates with six plants per strain. The average lesion length was classified as follows: resistant (lesion length 0 to $5 \mathrm{~cm}$ ), moderately resistant (lesion length 5.1 to $10 \mathrm{~cm}$ ), moderately susceptible (lesion length 10.1 to $15 \mathrm{~cm}$ ), and susceptible (lesion length $>15 \mathrm{~cm}$ ). In total, 10 accessions, including SUPA, were selected for resistance to $\mathrm{BB}$ under high temperature after evaluating 20 rice accessions in the greenhouse.

O. glaberrima genotyping using $\mathrm{X} \boldsymbol{a}$ gene markers. All the accessions were genotyped for the presence or absence of the resistance alleles of $\mathrm{Xa} 4, \mathrm{xa} 5, \mathrm{Xa}$, $x a 13$, and $\mathrm{Xa21}$. Rice genotypes IRBB4, IRBB5, IRBB7, IRBB13, and IRBB21 with resistance alleles $X a 4$, $x a 5, X a 7, x a 13$, and $X a 21$, respectively, were used as controls. IR24 was used as a susceptible allele control. Genomic DNA was extracted from each sample and control using the cetyltrimethylammonium bromide DNA extraction protocol. The genomic DNA was purified with RNase. The primer pairs used for $X a$ gene detection and their corresponding product size are listed in Table 2.

For Xa4 detection, 50 to $100 \mathrm{ng}$ of genomic DNA was used to detect resistant and susceptible alleles in a $10-\mu l$ polymerase chain reaction (PCR) according to the following cycles: initial denaturation at

Table 2. $X a$ gene-based and linked markers and size of their polymerase chain reaction (PCR) products

\begin{tabular}{|c|c|c|c|c|}
\hline Gene & Primer name & Sequence $\left(5^{\prime}\right.$ to $\left.3^{\prime}\right)$ & Type of marker & PCR products (bp) ${ }^{\mathrm{a}}$ \\
\hline \multirow[t]{2}{*}{$\overline{X a 4^{b}}$} & MP1_F & ATCGATCGATCTTCACGAGG & Linked & $\mathrm{S}=120$ \\
\hline & MP2_R & dTG CTA TAA AAG GCA TTC GGG & Linked & $\mathrm{R}=150$ \\
\hline \multirow[t]{3}{*}{$X a 5^{\mathrm{c}}$} & Xa5_F2_Sus & GCTCGCCATTCAAGTTCTTGTC & Gene-based & 198 \\
\hline & Xa5-F2-Res & GCTCGCCATTCAAGTTCTTGAG & Gene-based & $\ldots$ \\
\hline & Xa5_R2 & CCTTGATAGAAACCTTGCTCTTGAC & Gene-based & $\ldots$ \\
\hline \multirow[t]{2}{*}{$X a 7^{\mathrm{b}}$} & M5_F & CGATCTTACTGGCTCTGCAACTCTGT & Linked & $S=1170$ \\
\hline & M5_R & GCATGTCTGTGTCGATTGGTCCGTACGA & Linked & $R=294$ \\
\hline \multirow[t]{2}{*}{$X a 13^{b}$} & Xa13F_130-140 & CCT GAT ATG TGA GGT AGT & Gene-based & $S=1326$ \\
\hline & xa13R_1678-1662 & GAG AAA GGC TTA AGT GC & Gene-based & $\mathrm{R}=1523$ \\
\hline \multirow[t]{2}{*}{$X a 21^{\mathrm{b}}$} & Xa21 Forward & ATA GCA ACT GAT TGC TTG G & Gene-based & $S=1200$ \\
\hline & Xa21 Reverse & CGA TCG GTA TAA CAG CAA AAC & Gene-based & $\mathrm{R}=1400$ \\
\hline
\end{tabular}

\footnotetext{
a $\mathrm{S}=$ sensitive and $\mathrm{R}=$ resistant.

b Codominant primers.

c Dominant primers.
} 
$94^{\circ} \mathrm{C}$ for $4 \mathrm{~min} ; 32$ cycles of denaturation at $94^{\circ} \mathrm{C}$ for $1 \mathrm{~min}$, annealing at $58^{\circ} \mathrm{C}$ for $1 \mathrm{~min}$, and extension at $72^{\circ} \mathrm{C}$ for $2 \mathrm{~min}$; and a final extension step at $72^{\circ} \mathrm{C}$ for $8 \mathrm{~min}$.

For $x a 5$ allele detection, 10 to $20 \mathrm{ng}$ of genomic DNA was used in a $10-\mu l$ PCR according to the following cycles: initial denaturation at $94^{\circ} \mathrm{C}$ for $3 \mathrm{~min} ; 34$ cycles of denaturation at $94^{\circ} \mathrm{C}$ for $1 \mathrm{~min}$, annealing at $68^{\circ} \mathrm{C}$ for $1 \mathrm{~min}$, and extension at $72^{\circ} \mathrm{C}$ for $1 \mathrm{~min}$; and a final extension step at $72^{\circ} \mathrm{C}$ for $4 \mathrm{~min}$.

For $\mathrm{Xa7}, 50$ to $100 \mathrm{ng}$ of genomic DNA was used in a 10- $\mu \mathrm{l} \mathrm{PCR}$ according to the following cycles: initial denaturation at $94^{\circ} \mathrm{C}$ for $4 \mathrm{~min}$; 30 cycles of denaturation at $94^{\circ} \mathrm{C}$ for $30 \mathrm{~s}$, annealing at $60^{\circ} \mathrm{C}$ for $30 \mathrm{~s}$, and extension at $72^{\circ} \mathrm{C}$ for $2 \mathrm{~min}$; and a final extension step at $72^{\circ} \mathrm{C}$ for $8 \mathrm{~min}$.

The xal3 alleles were detected with 10 to $20 \mathrm{ng}$ of genomic DNA in a 10- $\mu 1$ PCR according to the following cycles: initial denaturation at $94^{\circ} \mathrm{C}$ for $4 \mathrm{~min} ; 30$ cycles of denaturation at $94^{\circ} \mathrm{C}$ for $1 \mathrm{~min}$, annealing at $60^{\circ} \mathrm{C}$ for $1 \mathrm{~min}$, and extension at $72^{\circ} \mathrm{C}$ for $2 \mathrm{~min}$; and a final extension step at $72^{\circ} \mathrm{C}$ for $8 \mathrm{~min}$.

Some 50 to $100 \mathrm{ng}$ of genomic DNA was used for $\mathrm{Xa21}$ alleles in a $10-\mu 1$ PCR according to the following cycles: initial denaturation at $94^{\circ} \mathrm{C}$ for $4 \mathrm{~min} ; 32$ cycles of denaturation at $94^{\circ} \mathrm{C}$ for $1 \mathrm{~min}$, annealing at $52^{\circ} \mathrm{C}$ for $1 \mathrm{~min}$, and extension at $72^{\circ} \mathrm{C}$ for $2 \mathrm{~min}$; and a final extension step at $72^{\circ} \mathrm{C}$ for 8 min.

The PCR products were separated in $1 \%$ agarose gel for $\mathrm{Xa}$, $x a 13$, and $\mathrm{Xa} 21$ and $2 \%$ for $\mathrm{Xa} 4$ and $x a 5$, then visualized under UV light.

Data analysis. The mean value from two replicated experiments was used for analysis of variance of BB lesion length. The significant difference $(P<0.001)$ in lesion length between accessions was assessed using the $F$ test. Statistical analysis was performed using the R package.

\section{Results}

Identification of $O$. glaberrima accessions with broad-spectrum resistance to Philippine $X$. oryzae pv. oryzae strains. $O$. glaberrima accessions and SUPA showed different reactions in response to the $14 X$. oryzae pv. oryzae strains (Fig. 1). O. sativa variety SUPA was susceptible to all the strains (Table 3; Supplementary Table $\mathrm{S} 1$ ). For the $O$. glaberrima accessions, all of them showed resistance to moderate resistance to PXO86 (race2), PXO79 (race3B), PXO347 (race9c), and PXO341 (race10). The majority of accessions were resistant to moderately resistant to PXO340 (race3C), PXO112 (race5), PXO145 (race7), PXO339 (race9A), and PXO349 (race9B). Strains PXO61, PXO71, PXO99, PXO363, and PXO280 were the most virulent, with $18,16,19,12$, and 10 accessions, respectively, being moderately susceptible to susceptible to them (Table 3 ). X. oryzae pv. oryzae strains PXO86, PXO79, PXO347, and PXO341 were less virulent on $O$. glaberrima accessions. Race 3 strains (PXO79, race 3B and $\mathrm{PXO} 340$, race 3C) induced different reactions on $O$. glaberrima. All the accessions were resistant and moderately resistant to PXO79.

O. glaberrima accessions TOG5953 and TOG6007 showed broadspectrum resistance to $12 X$. oryzae pv. oryzae strains and TOG5810, TOG5566, and TOG7173 were resistant to $11 X$. oryzae pv. oryzae strains. $O$. glaberrima accessions TOG5458 and TOG5523 were susceptible to six $X$. oryzae pv. oryzae strains (Table 3 ).

Accessions TOG5989 and TOG5473 were moderately susceptible and susceptible, respectively, to PXO340. Among race 9 strains, PXO363 (race 9d) was the most virulent, with only seven accessions showing resistance. Accessions CG17 and TOG5447 were moderately susceptible to race $9 \mathrm{a}$, and accession TOG5523 was moderately susceptible to race $9 \mathrm{~b}$. All the accessions were resistant to moderately resistant to race $9 \mathrm{c}$. Significant differences in lesion length were observed among all the accessions and differences were also significant among strains $(P<2.20 \mathrm{E}-16$; Table 4$)$.

High temperature enhances $O$. glaberrima resistance to $X$. ory$z a e$ pv. oryzae. $O$. glaberrima resistance to $X$. oryzae pv. oryzae was found to be enhanced under high temperature $\left(\mathrm{HT} ; 35\right.$ and $\left.31^{\circ} \mathrm{C}\right)$. BB resistance was evaluated in nine $O$. glaberrima accessions and SUPA. A majority of the accessions showed disease lesion length reduction and HT compared with the greenhouse study (Tables 5 and 6). Accession TOG5620 showed broad-spectrum resistance to all $X$. oryzae pv. oryzae strains, with moderate resistance to strains PXO71 and PXO99 under HT. Increase in lesion length under HT was observed in the accession-strain combinations CG17-PXO71; TOG5464-PXO339, PXO341, and PXO347; TOG5953-PXO71, PXO112, and PXO339; TOG7173-PXO339, PXO340, and PXO341; and SUPA-PXO61 and PXO145. Although most of the accessions showed lesion length reduction under high temperature, average lesion lengths induced by X. oryzae pv. oryzae strains PXO61, PXO71, and PXO99 were generally higher compared with lesion lengths induced by other strains.

The lesion lengths under each treatment were significantly different among treatments and among accessions and strains $(P=3.44 \mathrm{E}-11$; Tables 5 and 6). Accession TOG5523 showed the strongest BB disease reduction under HT and TOG5620 was the most resistant to majority of the $X$. oryzae pv. oryzae strains under HT.

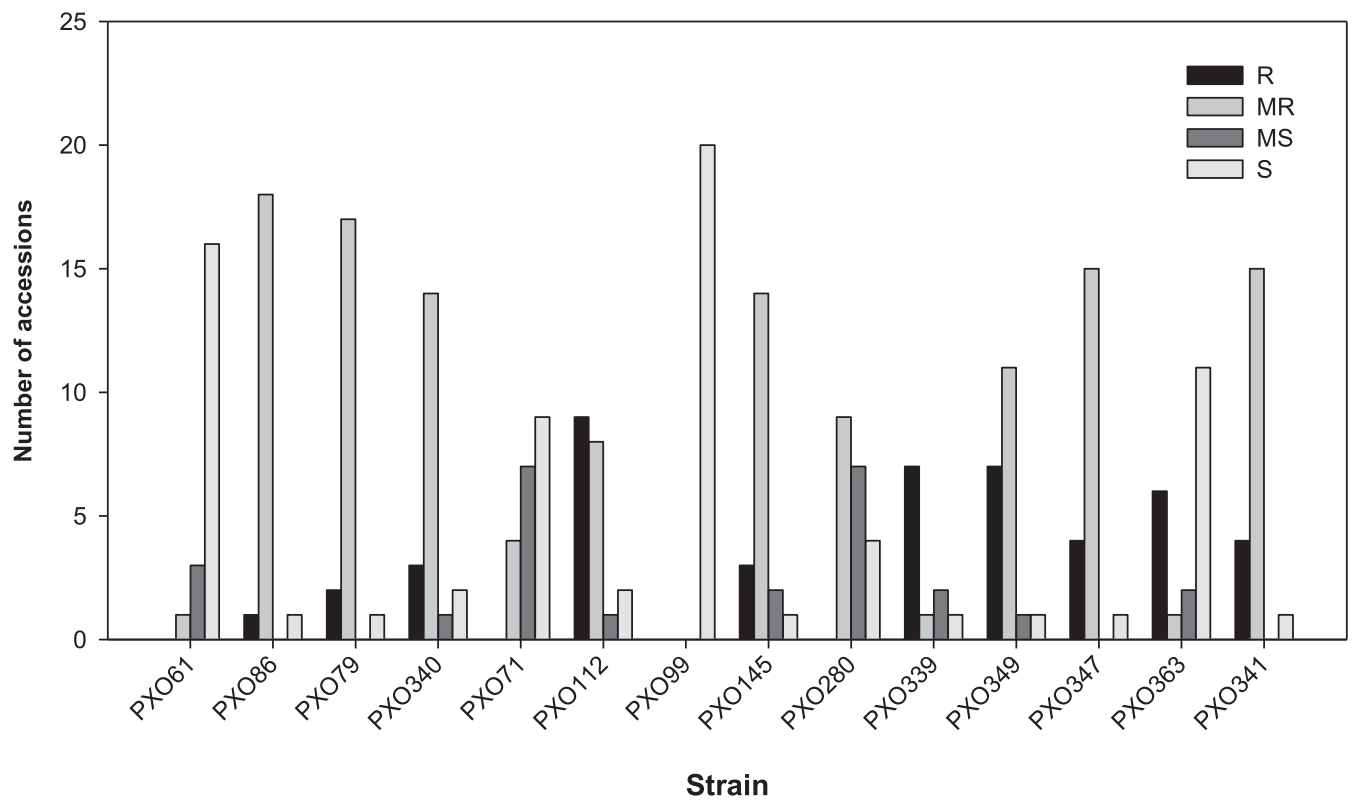

Fig. 1. Reaction of 20 rice accessions to 14 strains of Xanthomonas oryzae pv. oryzae from the Philippines. Bacterial blight lesion lengths were evaluated under greenhouse conditions at 2 weeks after inoculation. Lesion lengths were scored 14 days after inoculation. Lesion lengths: resistant $(R)=<5 \mathrm{~cm}$, moderately resistant (MR) $=>5$ to 10 $\mathrm{cm}$, moderately susceptible $(\mathrm{MS})=>10$ to $15 \mathrm{~cm}$, and susceptible $(\mathrm{S})=>15 \mathrm{~cm}$. 
Table 3. Oryza glaberrima reaction to 14 strains of Xanthomonas oryzae pv. oryzae from the Philippines under greenhouse conditions ${ }^{\text {a }}$

\begin{tabular}{|c|c|c|c|c|}
\hline Strains & $\mathbf{R}$ & MR & MS & $\mathbf{S}$ \\
\hline PXO61 (race 1) & $\ldots$ & TOG6007 & TOG5293, TOG5620, TOG7173 & $\begin{array}{c}\text { CG17, RAM90,RAM98, SUPA, } \\
\text { TOG5447, TOG5458,TOG5464, } \\
\text { TOG5473,TOG5523,TOG5566, } \\
\text { TOG5650,TOG5675,TOG5810, } \\
\text { TOG5953,TOG5989, TOG6231 }\end{array}$ \\
\hline PXO86 (race 2) & TOG7173 & $\begin{array}{l}\text { TOG6007,CG17,RAM90,RAM98, } \\
\text { TOG544, TOG5458,TOG5464, } \\
\text { TOG5473,TOG5523, TOG5566, } \\
\text { TOG5650,TOG5675,TOG5810, } \\
\text { TOG5953,TOG5989, TOG6231, } \\
\text { TOG5293, TOG5620 }\end{array}$ & $\cdots$ & SUPA \\
\hline PXO79 (race 3B) & TOG5650, TOG5810, & $\begin{array}{l}\text { CG17, RAM90, RAM98, } \\
\text { TOG5293, TOG5447, TOG5458, } \\
\text { TOG5464, TOG5473, TOG5523, } \\
\text { TOG5566, TOG5620,TOG5675, } \\
\text { TOG5953, TOG5989, TOG6007, } \\
\text { TOG6231, TOG7173 }\end{array}$ & $\cdots$ & SUPA, \\
\hline PXO340 (race 3C) & $\begin{array}{l}\text { TOG5566, TOG5953, } \\
\text { TOG6231 }\end{array}$ & $\begin{array}{l}\text { CG17, RAM90, RAM98, } \\
\text { TOG5293, TOG5447, TOG5458, } \\
\text { TOG5464,TOG5523, TOG5620, } \\
\text { TOG5650, TOG5675,TOG5810, } \\
\text { TOG6007, TOG7173 }\end{array}$ & TOG5989, & SUPA, TOG5473, \\
\hline PXO71 (race 4) & $\cdots$ & $\begin{array}{l}\text { CG17, RAM90, TOG5810, } \\
\text { TOG5953, }\end{array}$ & $\begin{array}{l}\text { TOG5523,TOG5566, TOG5620, } \\
\text { TOG5675, TOG5989, } \\
\text { TOG6231 }\end{array}$ & $\begin{array}{l}\text { RAM98, SUPA, TOG5293, } \\
\text { TOG5447, TOG5458, TOG5464, } \\
\text { TOG5473, TOG5650, TOG6007, } \\
\text { TOG7173 }\end{array}$ \\
\hline PXO112 (race 5) & $\begin{array}{l}\text { RAM90, TOG5566, } \\
\text { TOG5675, TOG5810, } \\
\text { TOG5953,TOG5989, } \\
\text { TOG6007, TOG6231, } \\
\text { TOG7173 }\end{array}$ & $\begin{array}{l}\text { CG17, TOG5293, TOG5447, } \\
\text { TOG5458, TOG5473, TOG5523, } \\
\text { TOG5620,TOG5650, }\end{array}$ & TOG5464, & RAM98, SUPA, \\
\hline PXO99 (race 6) & $\cdots$ & $\cdots$ & $\cdots$ & $\begin{array}{l}\text { CG17, RAM90, RAM98, SUPA, } \\
\text { TOG5293, TOG5447, TOG5458, } \\
\text { TOG5464, TOG5473, TOG5523, } \\
\text { TOG5566, TOG5620, TOG5650, } \\
\text { TOG5675, TOG5810, TOG5953, } \\
\text { TOG5989, TOG6007, TOG6231, } \\
\text { TOG7173 }\end{array}$ \\
\hline PXO145 (race 7) & $\begin{array}{l}\text { TOG5650, TOG5810, } \\
\text { TOG7173 }\end{array}$ & $\begin{array}{l}\text { CG17, RAM90, RAM98, } \\
\text { TOG5293, TOG5464, TOG5473, } \\
\text { TOG5523,TOG5566, TOG5620, } \\
\text { TOG5675, TOG5953,TOG5989, } \\
\text { TOG6007, TOG6231 }\end{array}$ & SUPA, TOG5447, & TOG5458 \\
\hline PXO280 (race 8) & & $\begin{array}{l}\text { RAM98, TOG5293, TOG5464, } \\
\text { TOG5566, TOG5675, TOG5810, } \\
\text { TOG5953, TOG6007, TOG7173 }\end{array}$ & $\begin{array}{l}\text { TOG5447,TOG5473,TOG5523, } \\
\text { TOG5620,TOG5650,TOG5989, } \\
\text { TOG6231 }\end{array}$ & CG17, RAM90, SUPA, TOG5458 \\
\hline PXO339 (race 9a) & $\begin{array}{l}\text { TOG5293,TOG5464, } \\
\text { TOG5473, TOG5566, } \\
\text { TOG5810,TOG5953, } \\
\text { TOG7173 }\end{array}$ & $\begin{array}{l}\text { RAM90, RAM98, TOG5458, } \\
\text { TOG5523, TOG5620, TOG5650, } \\
\text { TOG5675, TOG5989, TOG6007, } \\
\text { TOG6231 }\end{array}$ & CG17, TOG5447 & SUPA \\
\hline PXO349 (race 9b) & $\begin{array}{l}\text { TOG5293,TOG5464, } \\
\text { TOG5473, TOG5620, } \\
\text { TOG5810,TOG6231, } \\
\text { TOG7173 }\end{array}$ & $\begin{array}{l}\text { CG17, RAM90, RAM98, } \\
\text { TOG5447, TOG5458, TOG5566, } \\
\text { TOG5650,TOG5675, TOG5953, } \\
\text { TOG5989, TOG6007 }\end{array}$ & TOG5523 & SUPA \\
\hline PXO347 (race 9c) & $\begin{array}{l}\text { TOG5953, TOG6231, } \\
\text { TOG7173 }\end{array}$ & $\begin{array}{l}\text { CG17, RAM90, RAM98, } \\
\text { TOG5293, TOG5447, TOG5458, } \\
\text { TOG5464,TOG5523, TOG5566, } \\
\text { TOG5620, TOG5650,TOG5675, } \\
\text { TOG5810, TOG5989, TOG6007 }\end{array}$ & $\ldots$ & SUPA \\
\hline PXO363 (race 9d) & $\begin{array}{l}\text { TOG5464,TOG5473, } \\
\text { TOG5566, TOG5953, } \\
\text { TOG5989, TOG7173 }\end{array}$ & RAM98 & TOG5810, TOG6007 & $\begin{array}{l}\text { CG17, RAM90, SUPA, TOG5293, } \\
\text { TOG5447, TOG5458, TOG5523, } \\
\text { TOG5620, TOG6231, TOG5650, } \\
\text { TOG5675 }\end{array}$ \\
\hline PXO341 (race 10) & $\begin{array}{l}\text { TOG5566,TOG5675, } \\
\text { TOG5953, TOG7173 }\end{array}$ & $\begin{array}{l}\text { CG17, RAM90, RAM98, } \\
\text { TOG5293, TOG5447, TOG5458, } \\
\text { TOG5464,TOG5473, TOG5523, } \\
\text { TOG5620, TOG5650, TOG5810, } \\
\text { TOG5989, TOG6007, TOG6231 }\end{array}$ & $\ldots$ & SUPA \\
\hline
\end{tabular}

\footnotetext{
a Bacterial blight lesion lengths were evaluated under greenhouse conditions at 2 weeks after inoculation. Lesion lengths were scored 14 days after inoculation. Lesion lengths: resistant $(\mathrm{R})=<5 \mathrm{~cm}$, moderately resistant $(\mathrm{MR})=>5$ to $10 \mathrm{~cm}$, moderately susceptible $(\mathrm{MS})=>10$ to $15 \mathrm{~cm}$, and susceptible $(\mathrm{S})=>15 \mathrm{~cm}$.
} 
Rice $\mathrm{Xa}$ gene detection from $10 \mathrm{O}$. glaberrima accessions. All of the $O$. glaberrima accessions-SUPA, IR24, IRBB4, IRBB5, IRBB7, IRBB13, and IRBB21-were genotyped for the presence and absence of the Xa4, xa5, Xa7, xa13, and Xa21 alleles. All of the O. glaberrima accessions carried the susceptible alleles $X a 4, x a 5, x a 13$, and $X a 21$. No $\mathrm{X} a \mathrm{7}$ alleles were detected among $O$. glaberrima accessions and SUPA (Table 7). The Xa4-resistant allele was detected in SUPA. As expected, IRBB4, IRBB5, IRBB7, IRBB13, and IRBB21 showed resistant alleles $X a 4, x a 5, X a 7, x a 13$, and $X a 21$, respectively. The susceptible alleles were detected in IR24.

\section{Discussion}

Because resistance loss can occur any time due to pathogen adaptation and variability, a continuous search for new resistance traits is necessary. Continuous exploring of existing $\mathrm{BB} R$ genes or, alternatively, the search among cultivated and wild rice genotypes to discover new $R$ genes with broad-spectrum resistance would assist in containing the disease in the future, particularly under climate change. In this study, 19 cultivated African rice accessions evaluated for reaction to $\mathrm{BB}$ and combined $\mathrm{BB}$ and heat stresses showed different responses

Table 4. Variance analysis of average lesion length from 20 rice accessions inoculated with 14 X. oryzae pv. oryzae strains under greenhouse conditions ${ }^{\mathrm{a}}$

\begin{tabular}{lcrrc}
\hline Variable & Sum of squares & Df & $\boldsymbol{F}$ value & $\operatorname{Pr}(>\boldsymbol{F})$ \\
\hline Accession & $10,029.7$ & 19 & 68.5506 & $<2.20 \mathrm{E}-16^{* * *}$ \\
Strain & $20,340.7$ & 13 & 203.1897 & $<2.20 \mathrm{E}-16^{* * * *}$ \\
Accession $\times$ strain & $9,691.4$ & 247 & 5.0953 & $<2.20 \mathrm{E}-16^{* * *}$ \\
Residuals & $4,312.3$ & 560 & $\ldots$ & $\ldots$ \\
\hline
\end{tabular}

${ }^{a}$ Degrees of freedom $=$ Df: 14 X. oryzae pv. oryzae strains $(\mathrm{Df}=13)$ were used to inoculate 20 rice accessions $(\mathrm{Df}=19)$ under greenhouse conditions. Asterisks $(* * *)$ indicate the level of significance of each factor or between factors at $P$ value of 0.001 . to BB. One accession with broad-spectrum resistance to at least 12 Philippine strains was identified, suggesting that more $O$. glaberrima accessions should be evaluated to identify more accessions with broad-spectrum resistance to BB. Nevertheless, four, five, and six accessions were identified as having resistance to moderate resistance to 11,10 , and $9 X$. oryzae pv. oryzae strains, respectively, among the 14 strains. Our results are supported by previous reports which showed $O$. glaberrima accessions with broad-spectrum resistance to seven Indian X. oryzae pv. oryzae strains (Vikal et al. 2007) and resistance to West African X. oryzae pv. oryzae strains and the Philippine strain PXO86 (Djedatin et al. 2011). Moreover, the $O$. glaberrima accessions with broad-spectrum resistance reported by Vikal et al. (2007) were not included in this study, suggesting that $O$. glaberrima could be a store of resistance to several BB populations. Therefore, future studies are required to explore the $O$. glaberrima gene pool for the development of new resistance cultivars. A new $R$ gene for controlling BB in Asia, particularly in the Philippines, could be identified among $O$. glaberrima accessions. Furthermore, the use of broad-spectrum BB $R$ genes would reduce the development of new virulent strains, and broad-spectrum resistance traits among $O$. glaberrima could be introduced into $O$. sativa elite varieties through hybridization. Although a majority of the accessions ranged from moderately susceptible to susceptible to PXO61, accession TOG6007 showed susceptibility to only PXO71, PXO99, and $\mathrm{PXO} 363$.

Rice BB $R$ gene $\mathrm{X} a 4$ confers resistance to IRBB4 against PXO61 and has been widely used in Asia; however, the occurrence of new virulent strains affects the durability of $\mathrm{Xa} 4$ (Vera Cruz et al. 2000). We suggest that accession TOG6007 could be useful in areas dominated by Philippine race 1 strain. A majority of the accessions were susceptible to PXO61, PXO71, PXO99, PXO280, and PXO363. This could be explained by (i) the presence of conserved transcription activator-like (TAL) effectors in these strains that activate susceptibility genes among the selected $O$. glaberrima accessions $(n=4)$ and

Table 5. Bacterial lesion length on 10 rice accessions evaluated under greenhouse $(\mathrm{GH})$ and high temperature $(\mathrm{HT})$ conditions $^{\mathrm{a}}$

\begin{tabular}{|c|c|c|c|c|c|}
\hline Strains & CG17 & SUPA & TOG5464 & TOG5473 & TOG5523 \\
\hline PXO61 (race 1) GH & $25.5 \pm 2.43(\mathrm{~S})$ & $25.05 \pm 2.7(\mathrm{~S})$ & $19.4 \pm 2.02(\mathrm{~S})$ & $17.6 \pm 0.98(\mathrm{~S})$ & $16 \pm 1.49(\mathrm{~S})$ \\
\hline PXO61 (race 1) HT & $9.97 \pm 0.21(\mathrm{MR})$ & $27.03 \pm 2.03(\mathrm{~S})$ & $4.31 \pm 0.50(\mathrm{R})$ & $9.37 \pm 0.98(\mathrm{MR})$ & $12.24 \pm 0.84(\mathrm{MS})$ \\
\hline PXO86 (race 2) GH & $7.11 \pm 0.79(\mathrm{MR})$ & $19.04 \pm 2.11(\mathrm{~S})$ & $6.43 \pm 1.19(\mathrm{MR})$ & $7.15 \pm 1.42(\mathrm{MR})$ & $6.59 \pm 1.43(\mathrm{MR})$ \\
\hline PXO86 (race 2) HT & $2.40 \pm 0.1(\mathrm{R})$ & $11.14 \pm 0.92(\mathrm{MS})$ & $3.66 \pm 0.41(\mathrm{R})$ & $6.42 \pm 0.02(\mathrm{MR})$ & $2.91 \pm 0.31(\mathrm{R})$ \\
\hline PXO79 (race 3B) GH & $5.09 \pm 0.25(\mathrm{MR})$ & $16.11 \pm 1.02(\mathrm{~S})$ & $7.08 \pm 0.93(\mathrm{MR})$ & $6.12 \pm 0.23(\mathrm{MR})$ & $7.17 \pm 0.55(\mathrm{MR})$ \\
\hline PXO79 (race 3B) HT & $2.88 \pm 0.77(\mathrm{R})$ & $7.63 \pm 0.88(\mathrm{MR})$ & $4.35 \pm 0.13(\mathrm{R})$ & $3.13 \pm 0.83(\mathrm{R})$ & $6.44 \pm 1.41(\mathrm{MR})$ \\
\hline PXO340 (race 3C) $\mathrm{GH}$ & $7.17 \pm 1.57(\mathrm{MR})$ & $21.17 \pm 1.76(\mathrm{~S})$ & $5.31 \pm 0.93(\mathrm{MR})$ & $17.13 \pm 0.23(\mathrm{~S})$ & $8.15 \pm 0.84(\mathrm{MR})$ \\
\hline PXO340 (race 3C) HT & $2.18 \pm 0.58(\mathrm{R})$ & $11.48 \pm 1.23(\mathrm{MS})$ & $4.08 \pm 0.48(\mathrm{R})$ & $7.56 \pm 1.31(\mathrm{MR})$ & $2.53 \pm 1.13(\mathrm{R})$ \\
\hline PXO71 (race 4) GH & $7.68 \pm 0.89(\mathrm{MR})$ & $27.99 \pm 0.71(\mathrm{~S})$ & $21.65 \pm 0.84(\mathrm{~S})$ & $18.14 \pm 2.33(\mathrm{~S})$ & $12.95 \pm 2.12(\mathrm{MS})$ \\
\hline PXO71 (race 4) HT & $14.74 \pm 0.74(\mathrm{MS})$ & $15.75 \pm 1.99(\mathrm{~S})$ & $13.75 \pm 0.13(\mathrm{MS})$ & $15.06 \pm 1.11(\mathrm{~S})$ & $6.11 \pm 0.36(\mathrm{MR})$ \\
\hline PXO112 (race 5) GH & $6.01 \pm 2.52(\mathrm{MR})$ & $24.91 \pm 0.24(\mathrm{~S})$ & $13.46 \pm 0.65(\mathrm{MS})$ & $5.91 \pm 2.27(\mathrm{MR})$ & $5.44 \pm 1.97(\mathrm{MR})$ \\
\hline PXO112 (race 5) HT & $2.61 \pm 0.69(\mathrm{R})$ & $18.56 \pm 2(\mathrm{~S})$ & $3.99 \pm 0.57(\mathrm{R})$ & $8.43 \pm 0.93(\mathrm{MR})$ & $3.26 \pm 0.59(\mathrm{R})$ \\
\hline PXO99 (race 6) GH & $25.81 \pm 2.78(\mathrm{~S})$ & $28.92 \pm 1.12(\mathrm{~S})$ & $25.16 \pm 1.93(\mathrm{~S})$ & $25.19 \pm 0.74(\mathrm{~S})$ & $27.45 \pm 2.45(\mathrm{~S})$ \\
\hline PXO99 (race 6) HT & $5.19 \pm 0.34(\mathrm{MR})$ & $26.55 \pm 0.30(\mathrm{~S})$ & $12.33 \pm 0.21(\mathrm{MS})$ & $10.48 \pm 1.25(\mathrm{MS})$ & $3.45 \pm 0.21(\mathrm{R})$ \\
\hline PXO145 (race 7) GH & $7.89 \pm 1.66(\mathrm{MR})$ & $13.76 \pm 1.5(\mathrm{MS})$ & $6.6 \pm 1.36(\mathrm{MR})$ & $5.58 \pm 0.45(\mathrm{MR})$ & $8.63 \pm 0.1(\mathrm{MR})$ \\
\hline PXO145 (race 7) HT & $2.47 \pm 0.76(\mathrm{R})$ & $17.01 \pm 1.08(\mathrm{~S})$ & $3.55 \pm 0.65(\mathrm{R})$ & $5.26 \pm 0.25(\mathrm{MR})$ & $4.64 \pm 0.16(\mathrm{R})$ \\
\hline $\mathrm{PXO} 280$ (race 8$) \mathrm{GH}$ & $17.88 \pm 3.32(\mathrm{~S})$ & $28.26 \pm 2.42(\mathrm{~S})$ & $5.99 \pm 0.56(\mathrm{MR})$ & $14.5 \pm 2.46(\mathrm{MS})$ & $10.95 \pm 2.75(\mathrm{MS})$ \\
\hline $\mathrm{PXO} 280$ (race 8) HT & $5.68 \pm 0.68(\mathrm{MR})$ & $13.97 \pm 0.92(\mathrm{MS})$ & $4.62 \pm 0.74(\mathrm{R})$ & $4.49 \pm 1.04(\mathrm{R})$ & $4.06 \pm 0.01(\mathrm{R})$ \\
\hline PXO339 (race 9a) GH & $10.75 \pm 1.66(\mathrm{MS})$ & $29.22 \pm 2.81(\mathrm{~S})$ & $4.1 \pm 0.41(\mathrm{R})$ & $4.94 \pm 0.65(\mathrm{R})$ & $7.1 \pm 0.69(\mathrm{MR})$ \\
\hline PXO339 (race 9a) HT & $2.31 \pm 0.55(\mathrm{R})$ & $23.27 \pm 1.76(\mathrm{~S})$ & $13.87 \pm 1.09(\mathrm{MS})$ & $7.4 \pm 0.87(\mathrm{MR})$ & $7.49 \pm 1.21(\mathrm{MR})$ \\
\hline PXO349 (race 9b) GH & $7.25 \pm 2.79(\mathrm{MR})$ & $37.56 \pm 3.43(\mathrm{~S})$ & $4.78 \pm 1.03(\mathrm{R})$ & $4.87 \pm 0.97(\mathrm{R})$ & $12.34 \pm 1.65(\mathrm{MS})$ \\
\hline PXO349 (race 9b) HT & $3.10 \pm 0.88(\mathrm{R})$ & $24.99 \pm 1.01(\mathrm{~S})$ & $3.31 \pm 0.44(\mathrm{R})$ & $5.48 \pm 0.55(\mathrm{MR})$ & $4.51 \pm 0.33(\mathrm{R})$ \\
\hline PXO347 (race 9c) GH & $7.35 \pm 1.96(\mathrm{MR})$ & $28.46 \pm 2.45(\mathrm{~S})$ & $5.27 \pm 0.97(\mathrm{MR})$ & $4.92 \pm 0.80(\mathrm{R})$ & $5.32 \pm 1.41(\mathrm{MR})$ \\
\hline PXO347 (race 9c) HT & $1.92 \pm 0.58(\mathrm{R})$ & $19.02 \pm 1.87(\mathrm{~S})$ & $23.62 \pm 0.37(\mathrm{~S})$ & $3.97 \pm 0.7(\mathrm{R})$ & $3.27 \pm 0.84(\mathrm{R})$ \\
\hline PXO363 (race 9d) GH & $20.85 \pm 1.66(\mathrm{~S})$ & $17.15 \pm 1.2(\mathrm{~S})$ & $3.87 \pm 1.71(\mathrm{R})$ & $3.57 \pm 1.03(\mathrm{R})$ & $16.89 \pm 2.55(\mathrm{~S})$ \\
\hline PXO363 (race 9d) HT & $6.79 \pm 0.92(\mathrm{MR})$ & $9.22 \pm 2.03(\mathrm{MR})$ & $3.81 \pm 0.19(\mathrm{R})$ & $4.44 \pm 0.24(\mathrm{R})$ & $3.93 \pm 0.96(\mathrm{R})$ \\
\hline PXO341 (race 10$) \mathrm{GH}$ & $9.1 \pm 2.23(\mathrm{MR})$ & $23.13 \pm 2.62(\mathrm{~S})$ & $5.53 \pm 0.95(\mathrm{MR})$ & $5.58 \pm 0.67(\mathrm{MR})$ & $6.02 \pm 0.51(\mathrm{MR})$ \\
\hline PXO341 (race 10) HT & $2.38 \pm 0.48(\mathrm{R})$ & $23.71 \pm 0.22(\mathrm{~S})$ & $8.43 \pm 1.13(\mathrm{MR})$ & $3.66 \pm 0.68(\mathrm{R})$ & $7.16 \pm 0.76(\mathrm{R})$ \\
\hline
\end{tabular}

\footnotetext{
${ }^{a}$ Bacterial blight lesion lengths were evaluated under greenhouse (GH) and high temperature (HT) conditions at 2 weeks after inoculation. Lesion lengths were scored 14 days after inoculation. Each value is the mean \pm standard error. Mean values are followed by the standard error. Letters in parentheses are reaction categories based on lesion length. Lesion lengths: resistant $(\mathrm{R})=<5 \mathrm{~cm}$, moderately resistant $(\mathrm{MR})=>5$ to $10 \mathrm{~cm}$, moderately susceptible $(\mathrm{MS})=>10$ to $15 \mathrm{~cm}$, and susceptible $(\mathrm{S})=>15 \mathrm{~cm}$.
} 
(ii) the lack of resistant genes among these accessions that could recognize the avirulence protein of these strains. TAL effectors play an important role in the successful colonization of the host plant.

In this study, high temperature had generally shown positive effects on $O$. glaberrima resistance to BB. The lesion lengths induced by different $X$. oryzae pv. oryzae strains were generally reduced under high temperature in comparison with the greenhouse study, suggesting that $O$. glaberrima tolerance of abiotic stress enhanced its biotic stress response under high temperature. Resistance to abiotic and biotic stresses has been reported in O. glaberrima (Alam and Efron 1986; Albar et al. 2006; Baggie et al. 2002; Djedatin et al. 2011; Lorieux et al. 2003; Maji et al. 2001; Ndjiondjop et al. 1999; Nipah et al. 1997; Nwilene et al. 2002; Sahrawat and Sika 2002; Silue and Notteghem 1991; Thiémélé et al. 2010; Wang et al. 1996); however, none of the previous reports had shown a dual stress (abiotic and biotic) response. Thus, we suppose that $O$. glaberrima possesses traits that respond to combined stresses and could be useful for the improvement of $O$. sativa varieties. Although a reproductive barrier between $O$. glaberrima and $O$. sativa has been a major constraint to exploring the gene pool offered by $O$. glaberrima, further studies involving development of chromosome segment substitution lines to reduce hybrid sterility (Lorieux et al. 2013) are recommended to identify quantitative trait loci (QTL) responsible for abiotic and biotic stress in $O$. glaberrima to be used for development of interspecific hybridization between $O$. glaberrima and $O$. sativa (Ghesquière et al. 1997).

Conversely, a few combinations of strains and four accessions (CG17, TOG5464, TOG5953, and TOG7173), including SUPA, showed an increase in BB disease with high temperature, which suggests that more attention should be given for resistance durability under combined stresses through abiotic and biotic factors. This result was more often observed with $X$. oryzae pv. oryzae strains PXO71, PXO339, PXO341, and PXO347.

Previous reports have shown temperature effects on plant responses to pathogens. In rice, Webb et al. (2010) reported an increase in BB disease on IRBB4 and a reduction on IRBB7 under high temperature. A wheat variety with $R$ gene $\operatorname{Yr} 36$ showed broad-spectrum resistance to the wheat stripe rust (P. striiformis f. sp. tritici) at high temperature $\left(25\right.$ to $\left.35^{\circ} \mathrm{C}\right)$ but susceptibility at low temperature $\left(15^{\circ} \mathrm{C}\right)$ (Uauy et al. 2005). This suggests that identification of accessions that increase plant resistance and, thus, reduce pathogen aggressiveness under high-temperature conditions could play an important role in breeding rice varieties for combined stresses.

In this study, molecular characterization of $O$. glaberrima accessions and SUPA revealed that none of the $O$. glaberrima accessions possessed the resistance alleles $X a 4, x a 5, X a 7, x a 13$, and $X a 21$. Interestingly, $\mathrm{Xa} 7$ alleles were not detected in any of the accessions, suggesting that $O$. glaberrima lacks $\mathrm{X} a$. Moreover, resistance to PXO86 (avrXa7) may be conferred by a different type of $R$ gene in $O$. glaberrima. The absence of resistance alleles $\mathrm{X} a 4, \mathrm{xa} 13$, and $X a 21$ correlate with the phenotype data, because all the accessions were susceptible to PXO61 (except TOG6007) and PXO99. Although SUPA was susceptible to all $X$. oryzae pv. oryzae strains, the molecular characterization of SUPA was revealed to be homozygous for the $\mathrm{Xa} 4$ resistant allele. This suggests that the $\mathrm{Xa} 4$ resistant allele in SUPA is defective and, moreover, the Xa4 marker used in this study is not a linked marker.

The use of resistant cultivars remains the most effective control measure. Thirty-nine $R$ genes have been identified in rice (Khan et al. 2014; Natraj Kumar et al. 2012; Zhang et al. 2015), among which some of them, such as $\mathrm{Xa21}$, derived from wild rice, originate from O. longistaminata (Khush et al. 1990; Song et al. 1995), Xa23 from O. rufipogon (Zhang et al. 1998), Xa27 from O. minuta (Gu et al. 2004, 2005), and $X a 30(t)$ from $O$. nivara (Cheema et al. 2008). Wild rice genotypes are highly diverse due to natural selection and possess several traits that could be used for introgression of disease resistance in rice cultivars. Thus, mutations due to selection pressure could be transmitted from the ancestor to various cultivated accessions. Therefore, more attention should be given to African cultivated rice and its ancestor, $O$. longistaminata, and to other wild rice species, to identify traits of combined $\mathrm{BB}$ resistance and abiotic stress tolerance. PCR-based detection of $X a$ genes revealed no resistance alleles of $R$ genes studied here that could be associated with BB resistance. Therefore, we suggest the use of genome-wide association

Table 5. (continued from preceding page)

\begin{tabular}{|c|c|c|c|c|}
\hline TOG5566 & TOG5620 & TOG5953 & TOG5989 & TOG7173 \\
\hline $18.7 \pm 1.88(\mathrm{~S})$ & $14.3 \pm 1.74(\mathrm{MS})$ & $17.3 \pm 2.26(\mathrm{~S})$ & $19.04 \pm 1.83(\mathrm{~S})$ & $13.81 \pm 0.75(\mathrm{MS})$ \\
\hline $10.33 \pm 0.95(\mathrm{MS})$ & $5.31 \pm 0.89(\mathrm{MR})$ & $9.70 \pm 0.40(\mathrm{MR})$ & $16.07 \pm 2.53(\mathrm{~S})$ & $11.53 \pm 0.78(\mathrm{MS})$ \\
\hline $5.42 \pm 0.96(\mathrm{MR})$ & $8.04 \pm 0.74(\mathrm{MR})$ & $6.28 \pm 0.96(\mathrm{MR})$ & $5.88 \pm 0.84(\mathrm{MR})$ & $4.7 \pm 1.8(\mathrm{R})$ \\
\hline $3.22 \pm 0.53(\mathrm{R})$ & $2.98 \pm 0.25(\mathrm{R})$ & $2.83 \pm 0.53(\mathrm{R})$ & $2.29 \pm 0.47(\mathrm{R})$ & $5.04 \pm 0.07(\mathrm{MR})$ \\
\hline $7.31 \pm 1.47(\mathrm{MR})$ & $6.31 \pm 0.62(\mathrm{MR})$ & $6.49 \pm 1.53(\mathrm{MR})$ & $5.74 \pm 0.76(\mathrm{MR})$ & $6.5 \pm 1.01(\mathrm{MR})$ \\
\hline $3.61 \pm 0.85(\mathrm{R})$ & $2.63 \pm 0.48(\mathrm{R})$ & $2.74 \pm 0.59(\mathrm{R})$ & $3.14 \pm 0.66(\mathrm{R})$ & $2.85 \pm 0.78(\mathrm{R})$ \\
\hline $4.53 \pm 0.36(\mathrm{R})$ & $7.24 \pm 0.59(\mathrm{MR})$ & $4.93 \pm 0.73(\mathrm{R})$ & $13.05 \pm 0.5(\mathrm{MS})$ & $5.03 \pm 1.66(\mathrm{MR})$ \\
\hline $2.48 \pm 1.47(\mathrm{R})$ & $5.44 \pm 0.32(\mathrm{MR})$ & $2.27 \pm 0.61(\mathrm{R})$ & $4.55 \pm 0.13(\mathrm{R})$ & $15.37 \pm 1.79(\mathrm{~S})$ \\
\hline $11.63 \pm 2.98(\mathrm{MS})$ & $14.47 \pm 1.4(\mathrm{MS})$ & $9.91 \pm 2.35(\mathrm{MR})$ & $12.52 \pm 0.58(\mathrm{MS})$ & $15.38 \pm 1.58(\mathrm{~S})$ \\
\hline $13.15 \pm 0.97(\mathrm{MS})$ & $13.01 \pm 0.15(\mathrm{MS})$ & $14.84 \pm 0.86(\mathrm{MS})$ & $3.84 \pm 0.29(\mathrm{R})$ & $10.63 \pm 0.25(\mathrm{MS})$ \\
\hline $4.18 \pm 1.44(\mathrm{R})$ & $5.21 \pm 0.95(\mathrm{MR})$ & $4.82 \pm 1.65(\mathrm{R})$ & $4.16 \pm 1.25(\mathrm{R})$ & $3.84 \pm 1.35(\mathrm{R})$ \\
\hline $3.12 \pm 0.39(\mathrm{R})$ & $3.28 \pm 0.63(\mathrm{R})$ & $7.70 \pm 0.80(\mathrm{MR})$ & $4.78 \pm 0.77(\mathrm{R})$ & $3.56 \pm 0.44(\mathrm{R})$ \\
\hline $17.29 \pm 0.5(\mathrm{~S})$ & $24 \pm 2.49(\mathrm{~S})$ & $20.15 \pm 2.37(\mathrm{~S})$ & $24.44 \pm 3.57(\mathrm{~S})$ & $19.24 \pm 1.8(\mathrm{~S})$ \\
\hline $6.81 \pm 0.27(\mathrm{MR})$ & $12.08 \pm 1.98(\mathrm{MS})$ & $9.86 \pm 0.7(\mathrm{MR})$ & $5.08 \pm 0.7(\mathrm{MR})$ & $14.05 \pm 0.98(\mathrm{MS})$ \\
\hline $7.31 \pm 2.44(\mathrm{MR})$ & $8.5 \pm 1.77(\mathrm{MR})$ & $6.53 \pm 1.02(\mathrm{MR})$ & $8.73 \pm 0.93(\mathrm{MR})$ & $4.88 \pm 0.75(\mathrm{R})$ \\
\hline $4.39 \pm 1.02(\mathrm{R})$ & $3.42 \pm 0.12(\mathrm{R})$ & $4.15 \pm 0.0(\mathrm{R})$ & $7.28 \pm 0.48(\mathrm{MR})$ & $4.56 \pm 0.48(\mathrm{R})$ \\
\hline $6.96 \pm 1(\mathrm{MR})$ & $10.17 \pm 1.45(\mathrm{MS})$ & $9.1 \pm 0.84(\mathrm{MR})$ & $13.13 \pm 1.75(\mathrm{MS})$ & $7.3 \pm 0.5(\mathrm{MR})$ \\
\hline $1.94 \pm 0.19(\mathrm{R})$ & $4.10 \pm 0.85(\mathrm{R})$ & $13.92 \pm 1.62(\mathrm{MS})$ & $3.89 \pm 0.47(\mathrm{R})$ & $4.89 \pm 0.54(\mathrm{R})$ \\
\hline $4.93 \pm 1.11(\mathrm{R})$ & $5.86 \pm 0.86(\mathrm{MR})$ & $5 \pm 1.25(\mathrm{R})$ & $6.4 \pm 0.78(\mathrm{MR})$ & $3.65 \pm 0.8(\mathrm{R})$ \\
\hline $2.99 \pm 0.16(\mathrm{R})$ & $5.75 \pm 0.35(\mathrm{MR})$ & $2.82 \pm 0.67(\mathrm{R})$ & $4.03 \pm 0.63(\mathrm{R})$ & $7.63 \pm 0.57(\mathrm{MR})$ \\
\hline $7.22 \pm 1.14(\mathrm{MR})$ & $4.68 \pm 0.27(\mathrm{R})$ & $6.38 \pm 2.41(\mathrm{MR})$ & $5.76 \pm 0.56(\mathrm{MR})$ & $3.45 \pm 0.73(\mathrm{R})$ \\
\hline $2.04 \pm 0.17(\mathrm{R})$ & $5.27 \pm 0.34(\mathrm{MR})$ & $1.92 \pm 0.82(\mathrm{R})$ & $1.86 \pm 0.66(\mathrm{R})$ & $2.49 \pm 0.36(\mathrm{R})$ \\
\hline $6.22 \pm 0.84(\mathrm{MR})$ & $5.31 \pm 0.10(\mathrm{MR})$ & $4.75 \pm 1.13(\mathrm{R})$ & $6.2 \pm 0.80(\mathrm{MR})$ & $4.53 \pm 0.59(\mathrm{R})$ \\
\hline $6.0 \pm 0.11(\mathrm{MR})$ & $5.29 \pm 0.53(\mathrm{MR})$ & $16.07 \pm 2.04(\mathrm{~S})$ & $7.17 \pm 1(\mathrm{MR})$ & $5.36 \pm 0.63(\mathrm{MR})$ \\
\hline $4.56 \pm 1(\mathrm{R})$ & $19.45 \pm 2.59(\mathrm{~S})$ & $3.53 \pm 1.23(\mathrm{R})$ & $4.96 \pm 1.33(\mathrm{R})$ & $4.76 \pm 1.65(\mathrm{R})$ \\
\hline $7.62 \pm 1.34(\mathrm{MR})$ & $4.96 \pm 0.2(\mathrm{R})$ & $2.86 \pm 0.05(\mathrm{R})$ & $3.01 \pm 0.92(\mathrm{R})$ & $2.64 \pm 0.67(\mathrm{R})$ \\
\hline $4.39 \pm 0.33(\mathrm{R})$ & $6.18 \pm 1.18(\mathrm{MR})$ & $3.8 \pm 0.64(\mathrm{R})$ & $6.31 \pm 1.47(\mathrm{MR})$ & $4.58 \pm 0.41(\mathrm{R})$ \\
\hline $3.91 \pm 0.29(\mathrm{R})$ & $3.98 \pm 0.82(\mathrm{R})$ & $2.07 \pm 0.52(\mathrm{R})$ & $5.78 \pm 0.28(\mathrm{MR})$ & $5.63 \pm 0.14(\mathrm{MR})$ \\
\hline
\end{tabular}


Table 6. Variance analysis of bacterial blight lesion lengths from 10 rice accessions inoculated with $14 \mathrm{X}$. oryzae pv. oryzae strains under $35 / 31^{\circ} \mathrm{C}$ (day/night) temperature conditions ${ }^{\mathrm{a}}$

\begin{tabular}{|c|c|c|c|c|}
\hline Variables & Sum of squares & Df & $F$ value & $\operatorname{Pr}(>F)$ \\
\hline Strain & $5,078.7$ & 13 & 54.82 & $<2.20 \mathrm{E}-16^{* * * *}$ \\
\hline Stress & $5,799.2$ & 1 & 813.808 & $<2.20 \mathrm{E}-16^{* * *}$ \\
\hline Variety & $7,167.2$ & 9 & 111.7523 & $<2.20 \mathrm{E}-16^{* * * *}$ \\
\hline Strain $\times$ stress & $1,025.6$ & 13 & 11.0705 & $<2.20 \mathrm{E}-16^{* * *}$ \\
\hline Strain $\times$ accessions & $3,321.7$ & 117 & 3.9841 & $<2.20 \mathrm{E}-16^{* * *}$ \\
\hline Stress $\times$ accessions & 685.1 & 9 & 10.6821 & $3.10 \mathrm{E}-16 * * *$ \\
\hline Strain $\times$ stress $\times$ accessions & $2,097.0$ & 117 & 2.5151 & $3.44 \mathrm{E}-11 * * *$ \\
\hline Residuals & $1,995.3$ & 280 & $\ldots$ & $\ldots$ \\
\hline
\end{tabular}

a Degrees of freedom = Df. 14 X. oryzae pv. oryzae strains $($ Df $=13)$ were used to inoculate 10 rice accessions $($ Df $=9)$ under greenhouse and high temperature conditions ( $\mathrm{Df}=1)$. Asterisks $(* * *)$ indicate the level of significance of each factor or between factors at $P$ value of 0.001 .

Table 7. Allele analysis of Oryza glaberrima genotype using Xa4, xa5, Xa7, xa13, and Xa21 markers ${ }^{\mathrm{a}}$

\begin{tabular}{|c|c|c|c|c|c|c|c|c|c|c|c|c|c|c|c|}
\hline \multirow[b]{2}{*}{ Accession } & \multirow{2}{*}{$\begin{array}{r}x a 4 \\
(S)\end{array}$} & \multirow{2}{*}{$\begin{array}{r}X a 4 \\
(\mathbf{R})\end{array}$} & \multirow{2}{*}{$\begin{array}{r}x a 5 \\
(\mathbf{R})\end{array}$} & \multirow{2}{*}{$\begin{array}{c}X a 5 \\
(\mathrm{~S})\end{array}$} & \multirow{2}{*}{$\begin{array}{c}x a 7 \\
(S)\end{array}$} & \multirow{2}{*}{$\begin{array}{r}X a 7 \\
(\mathrm{R})\end{array}$} & \multirow{2}{*}{$\begin{array}{c}x a 13 \\
\text { (R) }\end{array}$} & \multirow{2}{*}{$\begin{array}{c}\text { Xa13 } \\
(\mathrm{S})\end{array}$} & \multirow{2}{*}{$\begin{array}{c}x a 21 \\
(\mathrm{~S})\end{array}$} & \multirow{2}{*}{$\begin{array}{c}X a 21 \\
(\mathrm{R})\end{array}$} & \multicolumn{5}{|c|}{ Genotype } \\
\hline & & & & & & & & & & & Xa4 & $x a 5$ & $X a 7$ & $x a 13$ & $X a 21$ \\
\hline CG17 & + & - & - & + & - & - & - & + & + & - & $x a 4 / x a 4$ & Xa5/Xa5 & - & Xa13/Xa13 & $x a 21 / x a 21$ \\
\hline RAM90 & + & - & - & + & - & - & - & + & + & - & $x a 4 / x a 4$ & $X a 5 / X a 5$ & - & Xa13/Xa13 & $x a 21 / x a 21$ \\
\hline RAM98 & + & - & - & + & - & - & - & + & + & - & $x a 4 / x a 4$ & $X a 5 / X a 5$ & - & Xa13/Xa13 & $x a 21 / x a 21$ \\
\hline SUPA & - & + & - & + & + & - & - & + & + & - & $X a 4 / X a 4^{b}$ & Xa5/Xa5 & $x a 7 / x a 7$ & Xa13/Xa13 & $x a 21 / x a 21$ \\
\hline TOG5293 & + & - & - & + & - & - & - & + & + & - & $x a 4 / x a 4$ & $X a 5 / X a 5$ & - & Xa13/Xa13 & $x a 21 / x a 21$ \\
\hline TOG5447 & + & - & - & + & - & - & - & + & + & - & $x a 4 / x a 4$ & Xa5/Xa5 & - & Xa13/Xa13 & $x a 21 / x a 21$ \\
\hline TOG5458 & + & - & - & + & - & - & - & + & + & - & $x a 4 / x a 4$ & Xa5/Xa5 & - & Xa13/Xa13 & $x a 21 / x a 21$ \\
\hline TOG5464 & + & - & - & + & - & - & - & + & + & - & $x a 4 / x a 4$ & $X a 5 / X a 5$ & - & Xa13/Xa13 & $x a 21 / x a 21$ \\
\hline TOG5473 & + & - & - & + & - & - & - & + & + & - & $x a 4 / x a 4$ & $X a 5 / X a 5$ & - & Xa13/Xa13 & $x a 21 / x a 21$ \\
\hline TOG5523 & + & - & - & + & - & - & - & + & + & - & $x a 4 / x a 4$ & Xa5/Xa5 & - & Xa13/Xa13 & $x a 21 / x a 21$ \\
\hline TOG5566 & + & - & - & + & - & - & - & + & + & - & $x a 4 / x a 4$ & $X a 5 / X a 5$ & - & Xa13/Xa13 & $x a 21 / x a 21$ \\
\hline TOG5620 & + & - & - & + & - & - & - & + & + & - & $x a 4 / x a 4$ & $X a 5 / X a 5$ & - & Xa13/Xa13 & $x a 21 / x a 21$ \\
\hline TOG5650 & + & - & - & + & - & - & - & + & + & - & $x a 4 / x a 4$ & $X a 5 / X a 5$ & - & Xa13/Xa13 & $x a 21 / x a 21$ \\
\hline TOG5675 & + & - & - & + & - & - & - & + & + & - & $x a 4 / x a 4$ & $X a 5 / X a 5$ & - & Xa13/Xa13 & $x a 21 / x a 21$ \\
\hline TOG5810 & + & - & - & + & - & - & - & + & + & - & $x a 4 / x a 4$ & $X a 5 / X a 5$ & - & Xa13/Xa13 & $x a 21 / x a 21$ \\
\hline TOG5953 & + & - & - & + & - & - & - & + & + & - & $x a 4 / x a 4$ & $X a 5 / X a 5$ & - & Xa13/Xa13 & $x a 21 / x a 21$ \\
\hline TOG5989 & + & - & - & + & - & - & - & + & + & - & $x a 4 / x a 4$ & $X a 5 / X a 5$ & - & Xa13/Xa13 & $x a 21 / x a 21$ \\
\hline TOG6007 & + & - & - & + & - & - & - & + & + & - & $x a 4 / x a 4$ & $X a 5 / X a 5$ & - & Xa13/Xa13 & $x a 21 / x a 21$ \\
\hline TOG6231 & + & - & - & + & - & - & - & + & + & - & $x a 4 / x a 4$ & Xa5/Xa5 & - & Xa13/Xa13 & $x a 21 / x a 21$ \\
\hline TOG7173 & + & - & - & + & - & - & - & + & + & - & $x a 4 / x a 4$ & $X a 5 / X a 5$ & - & Xa13/Xa13 & $x a 21 / x a 21$ \\
\hline IRBB4 & - & + & - & + & + & - & - & + & + & - & Xa4/Xa4 & Хa5/Хa5 & $x a 7 / x a 7$ & Xa13/Xa13 & $x a 21 / x a 21$ \\
\hline IRBB5 & + & - & + & - & + & - & - & + & + & - & $x a 4 / x a 4$ & $x a 5 / x a 5$ & $x a 7 / x a 7$ & Xa13/Xa13 & $x a 21 / x a 21$ \\
\hline IRRB7 & + & - & - & + & - & + & - & + & + & - & $x a 4 / x a 4$ & $X a 5 / X a 5$ & Xa7/Xa7 & Xa13/Xa13 & $x a 21 / x a 21$ \\
\hline IRBB 13 & + & - & - & + & + & - & + & - & + & - & $x a 4 / x a 4$ & Xa5/Xa5 & $x a 7 / x a 7$ & xa13/xa13 & $x a 21 / x a 21$ \\
\hline IRBB21 & + & - & - & + & + & - & - & + & - & + & $x a 4 / x a 4$ & Xa5/Xa5 & $x a 7 / x a 7$ & Xa13/Xa13 & Xa21/Xa21 \\
\hline IR24 & + & - & - & + & + & - & - & + & + & - & $x a 4 / x a 4$ & $X a 5 / X a 5$ & $x a 7 / x a 7$ & Xa13/Xa13 & $x a 21 / x a 21$ \\
\hline
\end{tabular}

a Symbols: + and - indicate presence or absence, respectively, of resistant (R) and susceptible (S) alleles.

b Defective resistance allele in SUPA.

mapping to identify possible QTL that are associated with BB resistance observed from $O$. glaberrima.

\section{Acknowledgments}

We thank R. Javier and C. Figuerra for providing technical support for greenhouse and growth-chamber experiments, and P. Grace Cañas for her critical review of the manuscript. This work was supported by BMZ through Mitigating the Impact of Climate Change on Rice Diseases in East Africa (MICCORDEAProject) and the Global Rice Science Partnership.

\section{Literature Cited}

Alam, M. S., and Efron, Y. 1986. Resistance to stalk eyed fly, Diopsis macroptholma. Dalman. Int. Rice Commun. Newsl. 31:40-45.

Albar, L., Bangratz-Reyser, M., Hébrard, E., Ndjiondjop, M.-N., Jones, M., and Ghesquière, A. 2006. Mutations in the eIF (iso) $4 \mathrm{G}$ translation initiation factor confer high resistance of rice to Rice yellow mottle virus. Plant J. 47:417-426.

Baggie, I., Zapata, F., and Sangina, N. 2002. Genotypic response to aluminium toxicity of some rice. Int. Rice Res. Notes. 27:42-43.

Cheema, K. K., Grewal, N. K., Vikal, Y., Sharma, R., Lore, J. S., Das, A., Bhatia, D., Mahajan, R., Gupta, V., Bharaj, T., and Singh, K. 2008. A novel bacterial blight resistance gene from Oryza nivara mapped to $38 \mathrm{~kb}$ region on chromosome 4L and transferred to Oryza sativa $\mathrm{L}$. Genet. Res. 90:397-407.
Cottyn, B., and Mew, T. 2007. Bacterial blight of rice. In: Encyclopedia of Plant and Crop Science. Marcel Dekker, Inc.

Das, B., Samik, S., Manoj, P., and Tapas, K. G. 2014. Genetic diversity of the conserved motifs of six bacterial leaf blight resistance genes in a set of rice landraces. BMC Genet. 15:82.

Djedatin, G., Ndjiondjop, M.-N., Mathieu, T., Vera Cruz, C. M., Sanni, A., Ghesquière, A., and Verdier, V. 2011. Evaluation of African cultivated rice Oryza glaberrima for resistance to bacterial blight. Plant Dis. 95:441-447.

Ghesquière, A., Séquier, J., Second, G., and Lorieux, M. 1997. First steps towards a rational use of African rice, Oryza glaberrima, in rice breeding through a 'contig line' concept. Euphytica 96:31-39.

Gu, K., Tian, D., Yang, F., Wu, L., Sreekala, C., Wang, D., Wang, G. L., and Yin, Z. 2004. High-resolution genetic mapping of $X a 27(t)$, a new bacterial blight resistance gene in rice. Oryza sativa L. Theor. Appl. Genet. 108:800-807.

Gu, K. Y., Yang, B., Tian, D. S., Wu, L. F., Wang, D. J., Sreekala, C., Yang, F., Chu, Z. Q., Wang, G. L., White, F. F., and Yin, Z. C. 2005. R gene expression induced by a type-III effectors triggers disease resistance in rice. Nature 435 . $1122-1125$

Jones, M. P., Ding Kuhn, M., Aluko, G. K., and Semon, M. 1997. Interspecific Oryza sativa L. $\times$ O. glaberrima Steud. progenies in upland rice improvement. Euphytica 94:237-246.

Kauffman, H. E., Reddy, A. P. K., Hsieh, S. P. Y., and Merca, S. D. 1973. An improved technique for evaluating resistance to rice varieties of Xanthomonas oryzae. Plant Dis. Rep. 57:537-541. 
Khan, M. A., Naeem, M., and Iqbal, M. 2014. Breeding approaches for bacterial leaf blight resistance in rice (Oryza sativa L.), current status and future directions. Eur. J. Plant Pathol. 139:27-37.

Khush, G. S., Bacalangco, E., and Ogawa, T. 1990. A new gene for resistance to bacterial blight from $O$. longistaminata. Rice Genet. Newsl. 7:121-122.

Leach, J. E., Rhoads, M. L., Vera Cruz, C. M., White, F. F., Mew, T. W., and Leung, H. 1992. Assessment of genetic diversity and population structure of Xanthomonas oryzae pv. oryzae with a repetitive DNA element. Appl. Environ. Microbiol. 58:2188-2195.

Lorieux, M., Garavito, A., Bouniol, J., Gutiérrez, A., Ndjiondjop, M. N., Guyot, R., Pompilio Martinez, C., Tohme, J., and Ghesquière, A. 2013. Unlocking the Oryza glaberrima treasure for rice breeding in Africa. Pages 130-143 in: Realizing Africa's Rice Promise. M. C. S. Wopereis, D. E. Johnson, N. Ahmadi, E. Tollens, and A. Jalloh, eds. CABI, Wallingford, UK.

Lorieux, M., Reversat, G., Garcia Diaz, S. X., Denance, C., Jouvenet, N., Orieux, Y., Bourger, N., Pando-Bahuon, A., and Ghesquière, A. 2003. Linkage mapping of Hsa-1Og, a resistance gene of African rice to the cyst nematode, Heterodera sacchari. Theor. Appl. Genet. 107:691-696.

Maji, T., Singh, B. N., and Akenova, M. E. 2001. Vegetative stage drought tolerance in $O$. glaberrima Steud and $O$. sativa L. and relationship between drought parameters. Oryza. 38:17-23.

Natraj Kumar, P., Sujatha, K., Laha, G. S., Srinivasa Rao, K., Mishra, B., Viraktamath, B. C., Hari, Y., Reddy, C. S., Balachandran, S. M., Ram, T., Sheshu Madhav, M., Shobha Rani, N., Neeraja, C. N., Ashok Reddy, G., Shaik, H., and Sundaram, R. M. 2012. Identification and fine-mapping of Xa33, a novel gene for resistance to Xanthomonas oryzae pv. oryzae. Phytopathology 102:222-228.

Ndjiondjop, M. N., Albar, L., Fargette, D., Fauquet, C., and Ghesquière, A. 1999. The genetic basis of high resistance to yellow mottle virus (RYMV) in cultivars of the two cultivated rice species. Plant Dis. 83:931-935.

Nipah, J. O., Jones, M. P., Singh, B. N., Kantaka, O. S., and Sahrawat, K. L. 1997. Screening for tolerance for iron toxicity. Int. Rice Res. Notes. 22:26-27.

Nwilene, F. E., Williams, U. T., Ukwungwu, M. N., Dakouo, D., Nacro, S., Hmadoun, A., and Kamara, S. I. 2002. Reactions of differential genotypes to African gall midge in West Africa. Intell. Pest Manage. 48:195-201.

Reddy, P. P. 2015. Impacts on crop protection. Pages 107-113 in: Climate Resilient Agriculture for Ensuring Food Security. Springer, New Delhi, India.

Sahrawat, K. L., and Sika, M. 2002. Comparative tolerance of O. sativa and O. glaberrima rice cultivars for iron toxicity in West Africa. Int. Rice Res. Notes. 27:30-31
Silue, D., and Notteghem, J. 1991. Resistance of 99 Oryza glaberrima varieties to blast. Int. Rice Res. Newsl. 16:13-14.

Song, W. Y., Wang, G. L., Chen, L. L., Kim, H. S., Pi, L. Y., Holsten, T., Gardner, J., Wang, B., Zhai, W. X., Zhu, L. H., Fauquet, C., and Ronald, P. 1995. A receptor kinase-like protein encoded by the rice disease resistance gene, Xa21. Science 270:1804-1806.

Thiémélé, D., Boisnard, A., Ndjiondjop, M.-N., Chéron, S., Séré, Y., Aké, S., Ghesquière, A., and Albar, L. 2010. Identification of a second major resistance gene to Rice yellow mottle virus, $R Y M V 2$, in the African cultivated rice species, O. glaberrima. Theor. Appl. Genet. 10:1300-1320.

Uauy, C., Brevis, J. C., Chen, X., Khan, I., Jackson, L., Chicaiza, O., Distelfeld, A., Fahima, T., and Dubcovsky, J. 2005. High-temperature adult-plant (HTAP) stripe rust resistance gene Yr36 from Triticum turgidum ssp. dicoccoides is closely linked to the grain protein content locus $G p c-B 1$. Theor. Appl. Genet. 112:97-105.

Vera Cruz, C. M., Bai, J. F., Ona, I., Leung, H., Nelson, R. J., Mew, T. W., and Leach, J. E. 2000. Predicting durability of a disease resistance gene based on an assessment of the fitness loss and epidemiological consequences of avirulence gene mutation. Proc. Natl. Acad. Sci. USA 97:13500-13505.

Vikal, Y., Das, A., Patra, B., Goel, R. K., Sidhu, J. S., and Singh, K. 2007. Identification of new sources of bacterial blight (Xanthomonas oryzae pv. oryzae) resistance in wild Oryza species and $O$. glaberrima. Plant Genet. Res. 5:108-112.

Wang, G. L., Song, W. Y., Ruan, D. L., Sideris, S., and Ronald, P. C. 1996. The cloned gene, Xa21, confers resistance to multiple Xanthomonas oryzae pv. oryzae isolates in transgenic plants. Mol. Plant-Microbe Interact. 9: $850-855$.

Webb, K. M., Ona, I., Bai, J., Garrett, K. A., Mew, T., Vera Cruz, C. M., and Leach, J. E. 2010. A benefit of high temperature: Increased effectiveness of a rice bacterial blight disease resistance gene. New Phytol. 185:568-576.

Yves, A., Biaou, S. S. H., Sié, M., Vodouhè, R. S., and Ahanchédé, A. 2012. The African Rice Oryza glaberrima Steud: Knowledge Distribution and Prospects. Int. J. Biol. 4:158-180.

Zhang, F., Zhuo, D.-L., Zhang, F., Huang, L.-Y., Wang, W.-S., Xu, J.-L., Vera Cruz, C., Li, Z.-K., and Zhou, Y.-L. 2015. Xa39, a novel dominant gene conferring broad-spectrum resistance to Xanthomonas oryzae pv. oryzae in rice. Plant Pathol. 64:568-575.

Zhang, Q., Lin, S. C., Zhao, B. Y., Wang, C. L., Yang, W. C., Zhou, Y. L., Li, D. Y., Chen, C. B., and Zhu, L. H. 1998. Identification and tagging a new gene for resistance to bacterial blight (Xanthomonas oryzae pv. oryzae) from O. rufipogon. Rice Genet. Newsl. 15:138-142. 